\title{
HIGH MORPHOLOGICAL VARIABILITY OF GERRIS ARGENTATUS SCHUMMEL 1832 (GERRIDAE) AND PROBABLY EUROPE'S SMALLEST GERRIDS, IN THE DANUBE DELTA (ROMANIA)
}

\author{
Horea OLOSUTEAN *, Codruța OLOSUTEAN * and Daniela ILIE **
}

* "Lucian Blaga" University of Sibiu, Faculty of Sciences, Department of Environmental Sciences and Physics, Dr. Ioan Rațiu Street 5-7, Sibiu, Romania, RO-550012, mesaje.facultate@yahoo.com, cocohorea@yahoo.com

** “Lucian Blaga” University of Sibiu, Faculty of Sciences, Applied Ecology Research Center, Dr. Ioan Rațiu Street 5-7, Sibiu, Romania, Sibiu, Romania, RO-550012, iliedf@yahoo.com

DOI: 10.2478/trser-2013-0023

KEYWORDS: Heteroptera, Gerris argentatus, wing polymorphism, Danube Delta.

\section{ABSTRACT}

On a field trip to the Busurca Canal, near Sulina, in the Danube Delta, an apterous Gerris argentatus male was captured. It measured only $5.1 \mathrm{~mm}$ from the tip of the head to the end of the last abdominal segment, and was the smallest adult pond skater recorded in Europe. This specimen was also the first to be describe as an apterous form of G. argentatus, the species previously being known as either macropterous or micropterous. A large macropterous male, measuring $6.77 \mathrm{~mm}$, was also collected in the same habitat, its size exceeding the known measurement for the species. Five G. argentatus females were taken from two sites on the Busurca Canal, each one measuring under the $7.5 \mathrm{~mm}$ length documented as a minimum for females of the species, with the smallest sample being only $6.59 \mathrm{~mm}$ in length.

ZUSAMMENFASSUNG: Die große morphologische Variabilität bei Gerris argentatus Schummel 1832 (Gerridae), die wahrscheinlich kleinste Gerriden-Art Europas im Donau-Delta (Rumänien).

Ein flügelloses Männchen von Gerris argentatus von lediglich 5,1 mm von der Kopfspitze bis zum letzten abdominalen Segment wurde während wissenschaftlichen Untersuchungen im Bursurca Kanal, nahe der Stadt Sulina im Donau-Delta gesammelt. Dabei handelt es sich um den kleinsten adulten Wasserläufer, der jemals in Europa dokumentiert wurde. Die flügellose Form wird ebenfalls erstmals für G. argentatus nachgewiesen, da die Art meist als Macro- oder Microptere bekannt ist. Im selben Habitat wurde ein großes macropteres Männchen festgestellt, das mit einer Länge von 6,77 mm die für diese Spezies bekannte Größe übertrifft. In zwei der untersuchten Habitate im Bursurca Kanal wurden fünf weibliche Exemplare gesammelt, deren Maße alle weniger als die üblichen, für diese Spezies dokumentierten 7,5 mm betrugen. Das kleinste Exemplar war lediglich 6,59 mm lang.

REZUMAT: Variabilitate morfologică mare la populații de Gerris argentatus Schummel 1832 (Gerridae), din Delta Dunării și probabil cel mai mic Gerrid al Europei (România).

Un mascul apter de Gerris argentatus a fost capturat într-o campanie de studiu pe Canalul Busurca, în apropiere de Sulina, în Delta Dunării, măsurând doar 5,1 mm de la extremitatea capului până la ultimul segment abdominal, exemplarul fiind cel mai mic Gerrid adult documentat pe continentul european. Forma apteră este, de asemenea, pentru prima dată menționată pentru G. argentatus, specie cunoscută ca macropteră sau micropteră. Un mascul de dimensiuni mari $(6,77 \mathrm{~mm})$ a fost capturat în același habitat, dimensiunea lui depășindu-le pe cele cunoscute pentru specia în cauză. Cinci femele au fost capturate în două habitate investigate pe Canalul Busurca, toate măsurând mai puțin decât cei $7,5 \mathrm{~mm}$ dați ca lungime minimă pentru specie, iar cea mai mică având doar $6,59 \mathrm{~mm}$. 


\section{INTRODUCTION}

Gerris argentatus Schummel 1832 is one of the most common pond skaters of Europe. Its presence is documented in all continental states of Europe, except Bosnia and Hertzegovina (Poisson, 1957; Aukema and Rieger, 1995; Aukema, 2004; Fent et al., 2011), and it is usually found in stagnant or slow-flowing waters in Romania, especially where hygrophilous vegetation is present (Paina, 1975; Davideanu, 1999). Although samples have been collected at over 1,500 $\mathrm{m}$ in the Romanian Carpathians, G. argentatus prefers lower altitudes (Davideanu, 1999; Ilie and Olosutean, 2009; Berchi et al., 2011), being regularly found in the Danube Delta (sampled at Caraorman and Crișan - Horváth, 1909; at Gorgova, Sfântu Gheorghe and on the Magearu Canal - Kiss and Davideanu, 1994; near Sulina Beach - Olosutean and Ilie, 2010).

Members of the Gerridae family are semi-aquatic true bugs characterized by a clear sexual dimorphism: the male is smaller than the female because of its reproductive system, with the male attaching on top of the female throughout the reproductive period.

G. argentatus is considered to be the smallest European member of the Gerridae family. Linnavuori (1966) and Nummelin et al. (1998) list species measurements between 6.5 and $8 \mathrm{~mm}$, though without discriminating between males and females. Poisson (1957) and later Davideanu (1999), however, categorize a 5.5 to $6.5 \mathrm{~mm}$ length for the male and a 7.5 to $8 \mathrm{~mm}$ margin for the female. Andersen (1993) extends the male's length down to $5.2 \mathrm{~mm}$ and the female's length up to 8.3, but returns to Poisson and Davideanu's measurements in a later paper (Andersen, 1996).

All authors present the species as macropterous or micropterous. Poisson (1957) describes macropterous individuals as usually larger than micropterous, launching the idea of a coherent relation between wing length and body length in the species.

\section{MATERIAL AND METHODS}

Biological material for the study was provided by quantitative samples taken in late August 2012, on the Busurca Canal of the Danube Delta, as part of a larger sampling campaign in the eastern Danube Delta. Each sample was collected over a twenty-five minute period using an entomological net with an $800 \mathrm{~cm}^{2}$ opening and two mm mesh screening, with the insects later being preserved in 70\% ethylic alcohol.

The species was identified using keys from Poisson (1957), Andersen (1993) and Davideanu (1999), while updated taxonomic information was provided by Fauna Europaea (Aukema, 2004).

All photographs and measurements were made using cellSens Entry v. $1.5\left({ }^{\odot}\right.$ Olympus Corporation), receiving data from an Olympus SZX 16 Stereo Microscope.

\section{RESULTS AND DISCUSSION}

G. argentatus individuals were found in only two of the nine habitats investigated in 2012, namely the stations encoded as R5 (around $10 \mathrm{~km} \mathrm{SSW}$ from the city of Sulina, $45^{\circ} 04^{\prime} 23.28$ ” N, 29 $35^{\prime}$ '52.89” E, altitude zero m), and R8 (around six km SSW from the city of Sulina, $45^{\circ} 06^{\prime} 42.64^{\prime \prime} \mathrm{N}, 29^{\circ} 35^{\prime} 43.08^{\prime \prime}$ E, altitude zero m) (Fig. 1).

At R5, a small, apterous $G$. argentatus male was collected with an individual measurement of $5102.78 \mu \mathrm{m}$ (Fig. 2) being smaller than the $5.5 \mathrm{~mm}$ usually given as the minimum length for the individual was the smallest $G$. argentatus officially recorded, and consequently became the smallest known European pond skater. It is also the first recording of an apterous G. argentatus because, all previous authors had labeled the species as either macropterous or micropterous (Poisson, 1957; Andersen, 1993, 1996; Davideanu, 1999). 


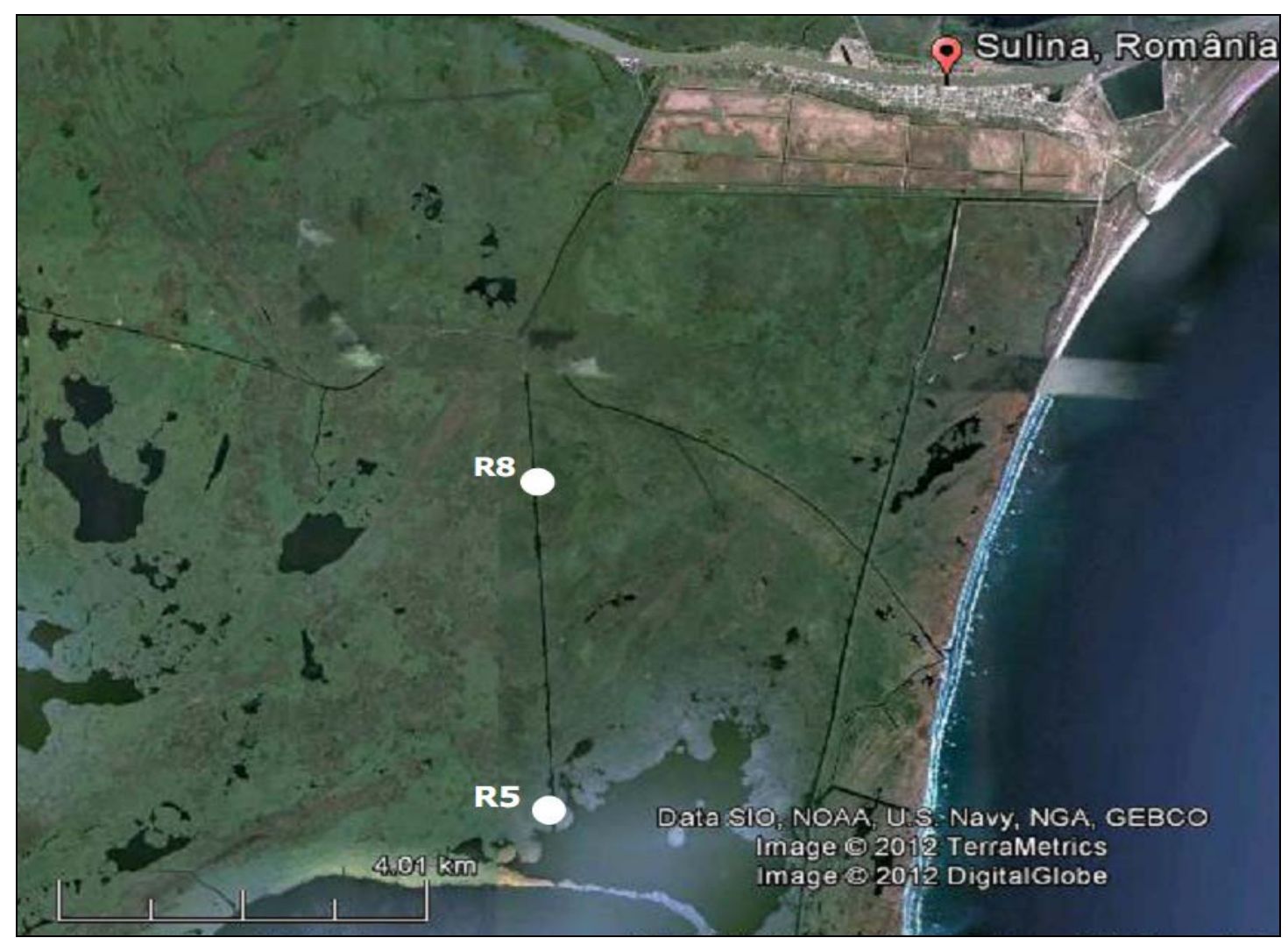

Figure 1: The location of the only two samples (R5 and R8) containing G. argentatus.

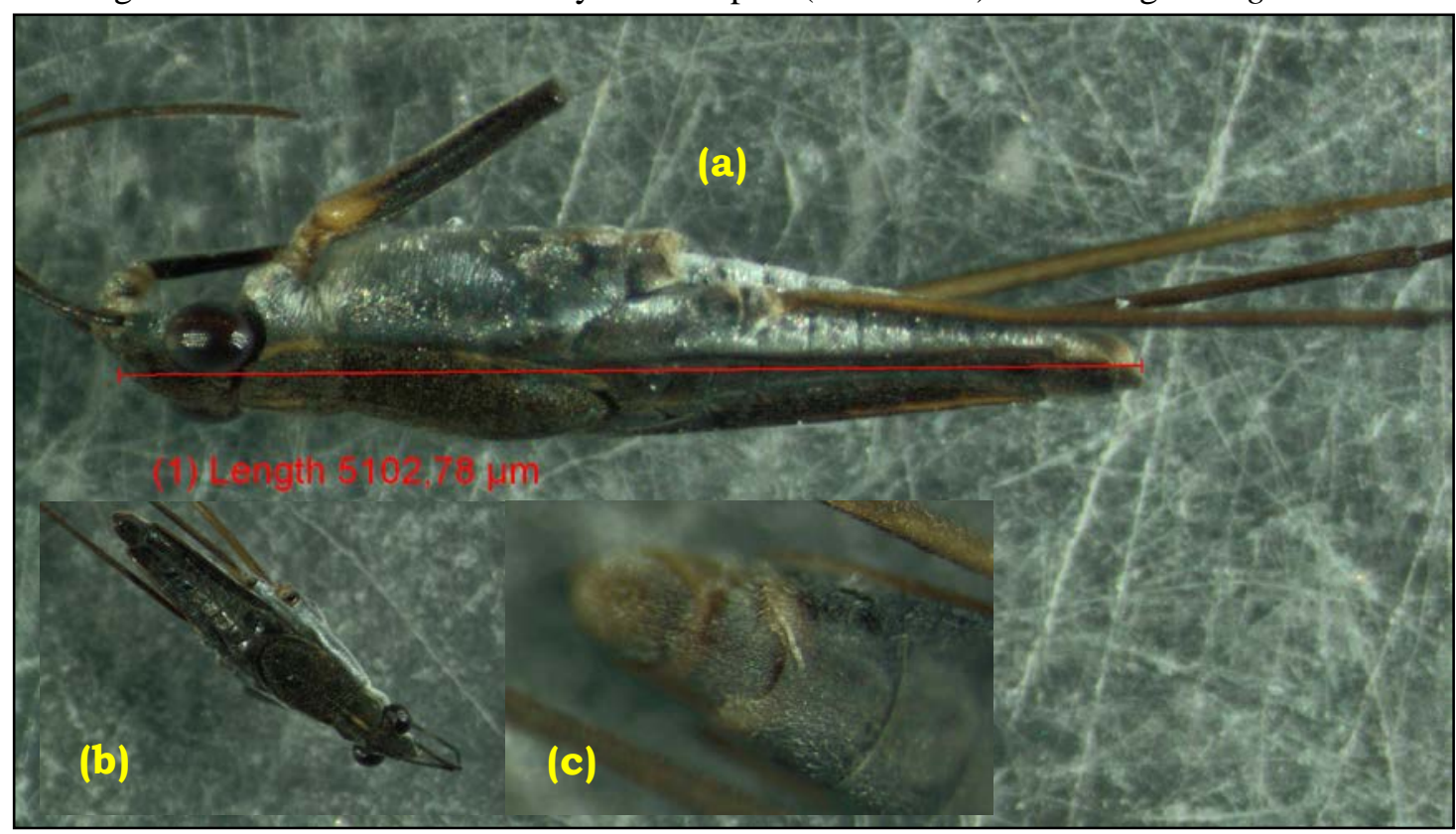

Figure 2: Small apterous G. argentatus male: a) lateral view; b) dorsal view; c) genital segments, ventral view. 


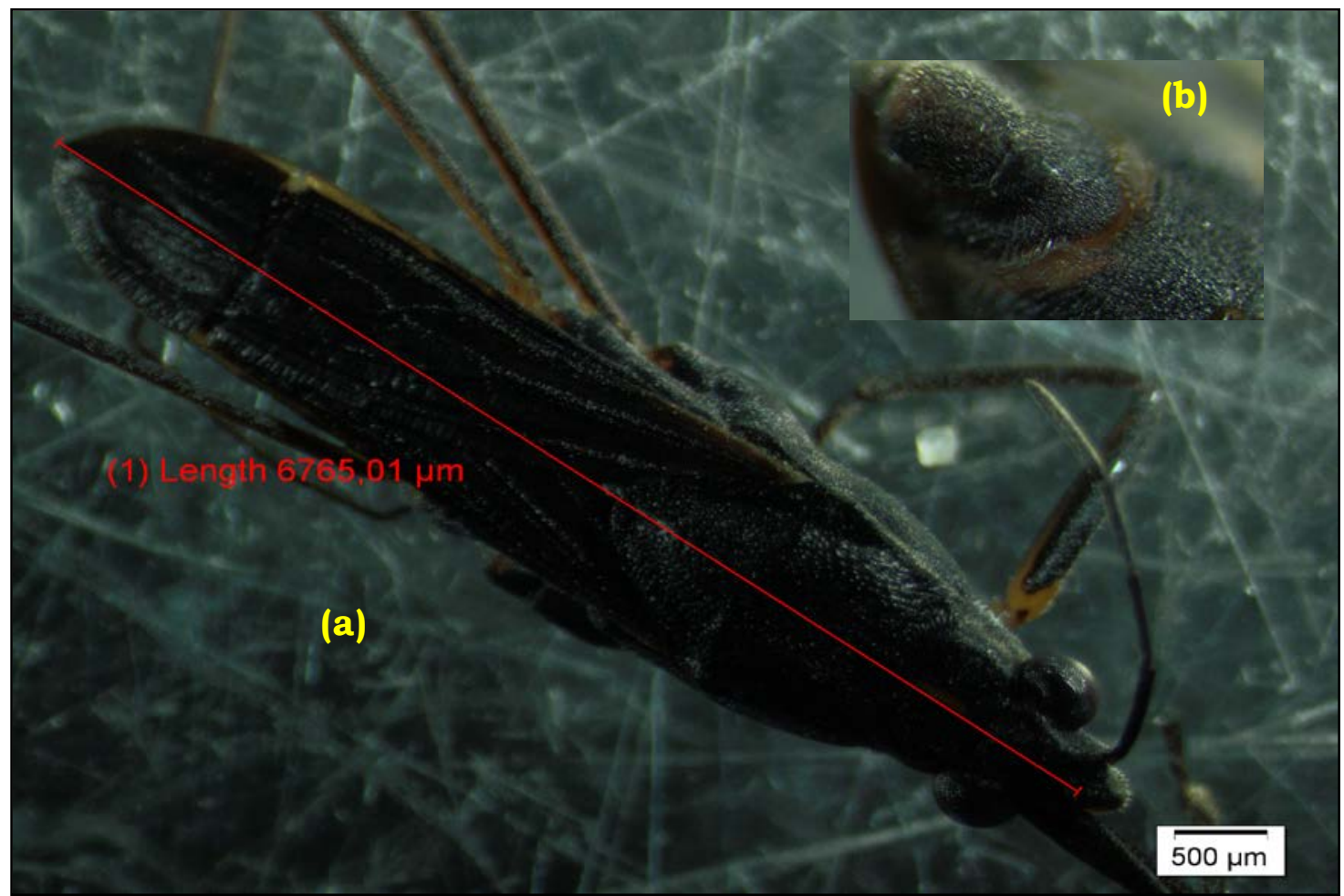

Figure 3: Large G. argentatus male: a) dorsal view; b) genital segments, ventral view.

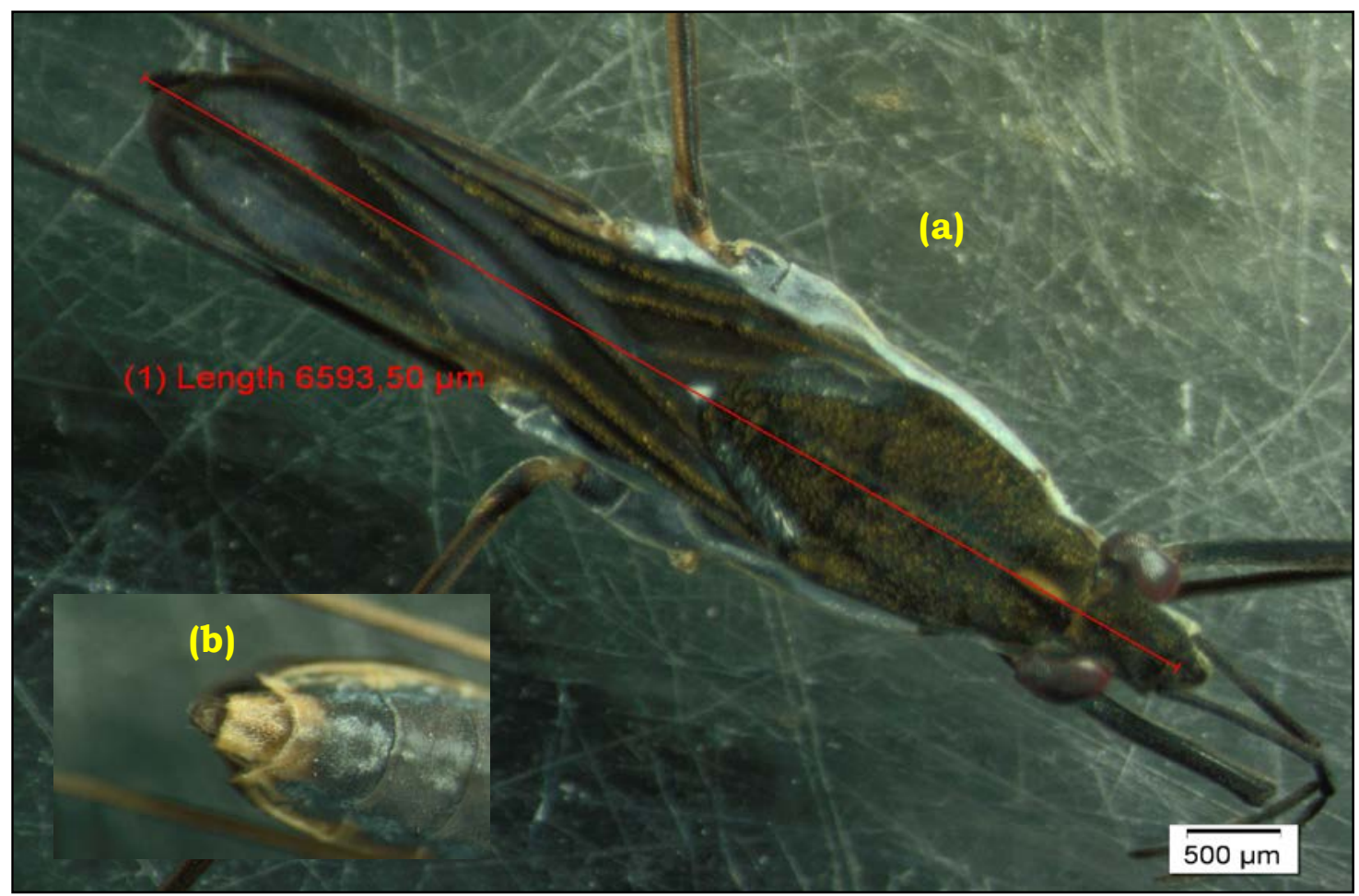

Figure 4: Small G. argentatus female: a) dorsal view; b) genital segments, ventral view. 
In the same sample there was a large, macropterous male measuring $6765.01 \mu \mathrm{m}$, which was larger than any known male specimen, making it the largest $G$. argentatus male recorded at that time (Fig. 3). Two G. argentatus females were also retrieved from the sample, with each measuring under the $7.5 \mathrm{~mm}$ given as the minimum size $(7252.03 \mu \mathrm{m}$ and 7350.01 $\mu \mathrm{m}$, respectively).

At R8, a sample of four $G$. argentatus adults was collected, all macropterous: one $5903.92 \mu \mathrm{m}$ male, and three small females, measuring $7060.64 \mu \mathrm{m}, 7144.46 \mu \mathrm{m}$ and 6593.50 $\mu \mathrm{m}$, respectively. The last individual (Fig. 4) was the smallest G. argentatus female ever recorded, over 12\% shorter than Poisson's (1957) and Davideanu's (1999) minimum length measurements.

R5 and R8 were the only two habitats sampled for G. argentatus during the 2012 campaign. European Frogbit (Hydrocharis morsus-ranae) was also found at R5 and R8 (Fig. 5), which probably provides suitable shelter for the small G. argentatus individuals; the relationship between the two species is currently under study.

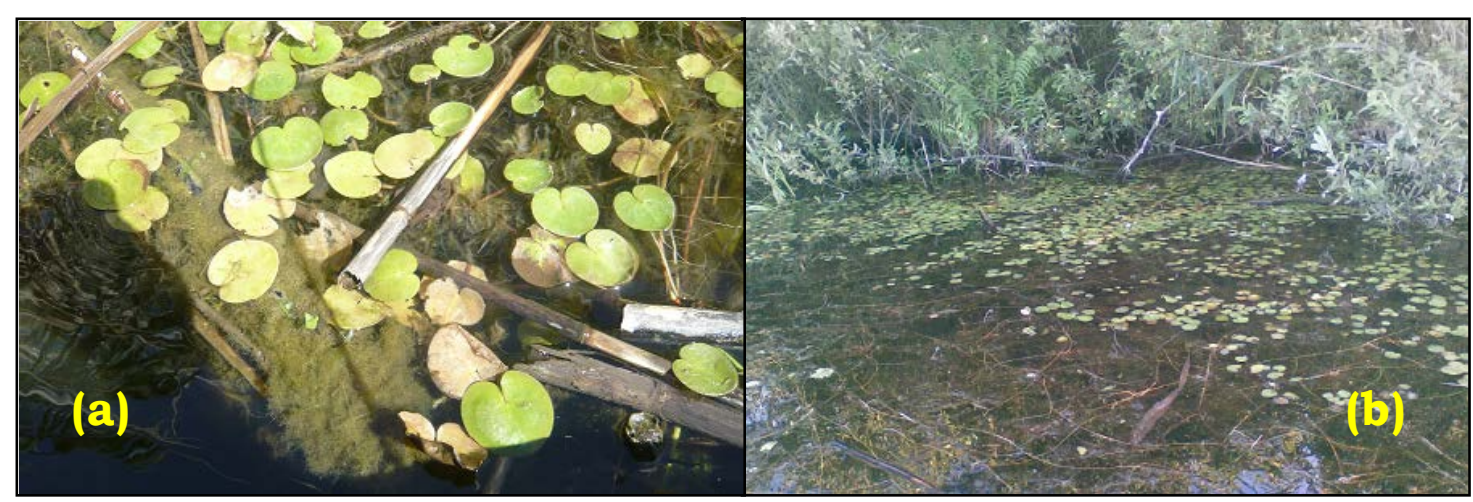

Figure 5: G. argentatus habitats:

a) typical vegetation, with Hydrocharis morsus ranae coverage;

b) gross-plan view of station R8.

The presence of several females that were smaller than the known minimum size of females, from other habitats, together with the small male, could be evidence of a smallersized population of G. argentatus in this specific area of the Danube Delta. These samples represent the smallest known European population of the Gerridae family. Since micropterous G. argentatus are presented as smaller than macropterous ones, there could be a relationship between apterous individuals and even smaller sized pond skaters of this particular species. This possible relationship will be investigated in future campaigns.

On the other hand, the presence of apterous and macropterous individuals and the relatively large size-variability of both males and females (e.g. the $32.5 \%$ difference in size between the smallest and the largest male) may lead to the conclusion that the Busurca Canal G. argentatus population has a large variability potential. If that is the case it would require, further field studies in order to determine the factors that may affect this variability, along with how important these factors are to the conservation of the species. 


\section{CONCLUSIONS}

The small population of $G$. argentatus, clearly outside the known measurements for the species, as well as the presence of apterous individuals, is showing that additional studies are necessary in order to establish the morphological range of the species. Large aquatic ecosystems, like the Danube Delta, might be the best locations for extensive studies on other semi-aquatic bugs, which, like $G$. argentatus, might prove to have a higher morphological capacity than what is known today.

\section{REFERENCES}

1. Andersen N. M., 1993 - Classification, phylogeny, and zoogeography of the pond skater genus Gerris Fabricius (Hemiptera: Gerridae), Canadian Journal of Zoology, 71, 2473-2508.

2. Andersen N. M., 1996 - Heteroptera Gerromorpha, Semiaquatic Bugs, in Nilsson A. N. (ed.), Aquatic insects of North Europe - A taxonomic handbook, Apollo Books, Stenstrup, 77-90.

3. Aukema B., 2004 - Fauna Europaea: Heteroptera, Nepomorpha, Fauna Europaea version 2.5, www.faunaeur.org, accesed at 06.022013.

4. Aukema B. and Rieger C., 1995 - Catalogue of the Heteroptera of the Palaearctic Region, 1, Enicocephalomorpha, Dipsocoromorpha, Nepomorpha, Gerromorpha and Leptopodomorpha, Netherlands Entomological Society, Amsterdam, 550.

5. Berchi G. M., Petrovici M. and Ilie D. M., 2011 - Aquatic and semiaquatic true bugs (Heteroptera: Nepomorpha) of Cefa Nature Park (North-Western Romania), Analele Universităţii din Oradea - Fascicula Biologie, XVIII, 1, 29-33.

6. Davideanu A., 1999 - Contribuţii la studiul heteropterelor acvatice din România, Ph.D. thesis, Babeș-Bolyai University, Cluj-Napoca, 257. (in Romanian)

7. Fent M., Kment P., Çamur-Elipek B. and Kirgiz T., 2011 - Annotated catalogue of Enicocephalomorpha, Nepomorpha, Gerromorpha and Leptopodomorpha (Hemiptera: Heteroptera) of Turkey, with new records, Zootaxa, 2856, 1-84.

8. Horváth G., 1909 - Poloska óriás a Magyar faunában, Állattani Közlemeények, VIII, 1-2, 141156. (in Hungarian)

9. Ilie D. M. and Olosutean H., 2009 - Aquatic and semiaquatic Heteroptera from Arieş River Basin: methods in estimating biodiversity, Transylvanian Review of Systematical and Ecological Research, The Arieş River Basin, Curtean-Bănăduc A. et al. (eds), 7, 77-86.

10. Kis B. and Davideanu A., 1994 - Heteroptere acvatice şi semiacvatice din Rezervaţia Biosferei Delta Dunării, Analele Ştiinţifice ale Institutului Deltei Dunării, 3, 149-154. (in Romanian)

11. Linnavuori R., 1966 - Suomen eläimet, Animalica Fennica, 10, Nivelkärsäiset 1, Hemiptera I, Luteet 1, Hydrocoriomorpha, Amphibiocoriomorpha ja Geocorisidae 1: Myridae, WSOY, Porvoo, 215. (in Finnish)

12. Nummelin M., Lodenius M. and Tulisalo E., 1998 - Water striders (Heteroptera, Gerridae) as bioindicators of heavy metal pollution, Entomologica Fennica, 8, 185-191.

13. Olosutean H. and Ilie D. M., 2010 - Aquatic and semiaquatic Heteroptera (Nepomorpha) from The Sulina-Sfântu Gheorghe Canal (Danube Delta, Romania), Transylvanian Review of Systematical and Ecological Research, Curtean-Bănăduc A. et al. (eds), 10, 55-76.

14. Paina I., 1975 - Lista Heteropterelor acvatice şi semiacvatice (O. Heteroptera) din R. S. România, Nymphaea, III, 99-115. (in Romanian)

15. Poisson R., 1957 - Faune de France, 61, Hétéroptères Aquatiques, Librairie de la Faculte des Sciences, Paris, 263. (in French) 